\begin{abstract}
This article considers Nina Bouraoui's Garçon manqué (Paris, 2000) within the generic framework of the life narrative, and from the thematic perspective of illness. Exploring nuances of identity and sexuality within the narrative, the article investigates the re-claiming of gendered, social, and sexual subjectivity implicit in the self-referential literary project. The discussion is underpinned by theories of the "sick" body, and the analysis identifies and explores primordial notions of identity, trauma, and social "normality" within the narrative.

Keywords: illness, identity, embodiment, silence, truth, autobiography, memory, agency, sexuality
\end{abstract}




\section{WOUNDED STORYTELLER: ILLNESS AS LIFE NARRATIVE IN NINA BOURAOUI'S GARÇON MANQUÉ}

WHILE NINA BOURAOUI has recently come to the fore in the context of post-colonial women's writing, and for the accolade of the Prix Renaudot (awarded for her latest novel Mes Mauvaises Pensées in 2005), nonetheless the intriguing crises of identity and sexuality explored in her first autobiographical narrative Garçon manqué remain largely unexplored. ${ }^{1}$ In this article, I analyse aspects of identity and sexuality in Garçon manqué firstly within the generic terms of "life narrative", and secondly by interrogating the theme of illness throughout the narrative. ${ }^{2}$ Applying to Garçon manqué Arthur Frank's theorisation of the "Wounded Storyteller" and Susan Sontag's notion of "illness as metaphor", ${ }^{3}$ I consider primordial questions of identity, trauma, and social "normality" within the life narrative. All of these are intimately linked to the lesbian body, and so I open up not only the restrictions of Bouraoui's "othered" social and sexual role, but also her strategies for survival as agent of her own subjectivity. My investigation of this re-claiming of subjectivity will be navigated generically via discussion of the life narrative, and thematically through a study of illness within the narrative. Firstly, I establish and interrogate the generic parameters which frame my debate. Then, I move on to a tri-partite 
discussion of Bouraoui's representation of illness within the life narrative, considering silence as a cause of social dis-ease, the physical embodiment of this dis(-)ease, and the uncovering of truth as "healing" practice. Expressing "une identité de fracture" within autobiography and the illness narrative

While not claiming to be purely autobiographical, nonetheless $G M$ is selfreferential, and so throughout my discussion I shall differentiate between authorial and narrative voice by making a distinction between Bouraoui as author and Nina as narrator. By inscribing her personal experience onto her narrative, Bouraoui exemplifies Elizabeth Fallaize's analysis of contemporary Francophone women's writing, that "with its sense that the personal is political and its desire to address areas of women's experience previously silenced or fantasised in literature, was always likely to deal with autobiographical issues", as well as upholding Debra Kelly's assertion that post-colonial writing "privilege[s] a political agenda as well as a personal one". Within this highly personal narrative, the "political" nature of lesbianism within a patriarchal context, and the historical conflict which frames the individual struggle, embrace Fallaize's claim regarding the intrinsic autobiographical nature of Francophone women's writing, and 
Kelly's regarding the explicit political engagement in North African Francophone writing.

Although GM does appear to conform broadly to Philippe Lejeune's much-cited definition of autobiography as "un récit rétrospectif en prose qu'une personne réelle fait de sa propre existence, lorsqu'elle met l'accent sur sa vie individuelle, en particulier sur l'histoire de sa personnalité", 5 the social and sexual nuances in the text merit closer consideration within more contemporary theories of autobiography and the narrative of self. $G M$ can certainly be seen to conform to Domna Stanton's more recent profeminine notion of "autogynography", which highlights the importance of gendered subjectivity to the production of self-referential literature, claiming that women's autobiographical writing has "a global and therapeutic purpose: to constitute the female subject. ${ }^{96}$ However, if we were to claim $G M$ as strictly autogynographical writing, we could potentially fall into another essentialist trap, that of presenting female autobiography within the parameters of a white, colonial mould which does not attempt to rethink post-colonial narratives of sexual and social difference. ${ }^{7}$ Therefore, while there are undoubtedly autobiographical, and indeed autogynographical aspects of $G M$ - its hesitant self-interrogation fitting into Michael Sheringham's description of autobiography as an 
"anxious genre", and its marked otherness reflecting Leah Hewitt's claim that "there are very distinct contours for the female autobiographical 'I",8 I propose that it can best be interrogated within the parameters of "life narrative", given its engagement with the essential components of the life narrative as outlined by Sidonie Smith and Julia Watson: memory, experience, identity, embodiment, and agency (RA, p. 3$){ }^{9}$

Within the broader considerations of the life narrative, I also argue for the importance of $G M$ as illness narrative. Although $G M$ does not conform to conventional expectations of the illness narrative, in that it does not recount a specific physical illness, I propose that we can better explore the nuances of the text by applying social theories of writing physical disease to Bouraoui's attempts to write of her social dis-ease. Indeed, Arthur Frank notes that "illness narratives as one form of self-story overlap with and are bound by at least three other forms. These are spiritual autobiographies, stories of becoming a man or a woman and what that gender identity involves, and finally survivor stories of inflicted traumas such as war, captivity, [...] and abuse" (WS, p. 69). Bouraoui's quest to establish and come to terms with her own identity illustrates Frank's notion of a "spiritual autobiography", and nowhere is the story of becoming a man or a woman, and the implications of that gender identity, more explicit than 
in Nina's lament: “J'ai quatre problèmes. Fille? Garçon? Française? Algérienne?" (p. 163). While there is in GM a reference to abuse, cited by Frank as one possible "inflicted trauma", I would argue that the true inflicted trauma in this narrative is simultaneously the "war" of Bouraoui's historical and familial heritage ("Je viens de la guerre. Je viens d'un mariage contesté", p. 32), and the "captivity" of social expectation ("Je joue à l'intérieur de ma prison", p. 18). Finally, Susan Sontag's claims that "illness is $[\ldots]$ basically, a psychological event" (IM, p. 58), and that "disease imagery is used to express concern for social order" (p. 73), consolidate my argument for $G M$ as illness narrative, given the way in which Bouraoui reverses notions of "normality" and "well-being" within the narrative, all of which hinges on her psychological restrictions and selfinterrogation. For example, Bouraoui recounts the difficulties of growing up with the triple stigma of being a woman in a male-dominated community: "Bouraoui de raha conter et de $A b i$ qui signifie le père. Les noms arabes sont des prisons familiales. On est toujours le fils de avec Ben ou le père de avec Bou. Des prisons familiales et masculines" (p. 124), living in Algeria but being half-French: 'J'ai deux passeports. Je n'ai qu'un seul visage apparent. Porter une identité de fracture" (p. 19), and being a lesbian: "Je ne sais pas qui je suis. [...] Forte et fragile. Fille et 
garçon. Mon corps me trahira un jour” (p. 60). Nina has difficulty negotiating a place for herself within the suffocating environment around her: the social and family contexts are incarcerating, as there is no space within their rigid parameters to accommodate any aspect of her "fractured identity".

Nina's divided nationality is a significant cause of her social "othering": the union of her French mother and Algerian father bore the stigma of taboo, evidenced in her mother's family's opposition to the marriage. This rejection by her family led Nina's mother to pass on her own dis(-)ease to her daughter: "Longtemps je porterai en moi l'enfance de ma mère. Comme un héritage. Comme une blessure à effacer par ma vie heureuse. [...] Longtemps je la porterai pour soulager ma mère. Pour la guérir. [...] Longtemps je prendrai ses peurs" (p. 114, my italics). The past (or "memory", to frame the debate within Smith and Watson's terms) is portrayed as a wound that can only be healed by Bouraoui's embodiment of dis-ease ("je porterai en moi"; "je prendrai ses peurs"), taking on her mother's fears and troubled history in her own quest for identity and acceptance. Memory and experience afflict Nina, transmitted like an illness ("Je porte ces transmissions-là", p. 32), as she is accepted neither as Algerian nor as French: "Je suis indéfinie. [...] Je deviens inclassable. Je 
ne suis pas assez typée. 'Tu n'es pas une Arabe comme les autres.' Je suis trop typée. 'Tu n'es pas française”' (p. 33). The twofold sense of "indéfinie", meaning both undefined and indefinite, shows how Nina's identity is unstable not only because of a lack of words or "type" in which to define her, but also because her nationality and sexuality are not recognised as being acceptable within the conceptual framework of the society in which she operates. Therefore, conforming to Frank's hypothesis that "most published illness stories are quest stories" (WS, p. 115), through her writing Bouraoui is searching for a fixed identity: "Je reste entre deux identités. Mon équilibre est dans la solitude, une unité. J'invente un autre monde. [...] Sans jugement. [...] J'apprends à écrire" (p. 26). Indeed, it is precisely Nina's separation between two identities that approximates this text to the illness narrative: her claim that "je suis impuissante. Je reste une étrangère. Je suis invalide" (p. 12, my italics) plays on the dual meaning of "invalide" as both unwell and not legitimate, her lack of social "validity" rendering her a metaphorically "ill" subject, one who must tell her story in order to survive.

Overcoming social silence and silencing through the life narrative Within the wider debates on nationality and sexuality, it is the lack of voice - and the active silencing of desire - that is at the root of Nina's identity 
crisis. Finding a voice is thus Nina's greatest challenge: as Frank states, "seriously ill people are wounded not just in body but in voice. They need to become storytellers in order to recover the voices that illness and its treatment often take away" (WS, p. xii). While Nina may not be suffering from a medically diagnosed illness, the pressure on her to conform to expectations of "normality" can be likened to the "treatment" referenced by Frank. Nina attempts to fit in with the versions of femininity that she is told she ought to embody: "Faire semblant. Porter de vraies chaussures. Des chaussures qui ferment. Ne pas manger avec ses doigts. Dire bonjour et merci. Porter des robes. Se taire" (p. 95). However, none of these models of femininity sit well with Nina, as she is always aware that she is "pretending" to be a girl. Moreover, all of these stereotypes are in some way physically or linguistically restrictive, and the culmination of all of them in the phrase "se taire" encapsulates Nina's earlier assertion that "le silence prend le lieu. Il ressemble à la mort" (p. 23). To give in to the attempted silencing of her difference is seen as equivalent to accepting death, which further highlights the relevance of the illness narrative in $G M$.

Corroborating Frank's claim that "women's enemy is silence" (WS, p. 121), Bouraoui evokes specifically the notion of silence as dis-ease: "Mais le silence prendra tout. Silence sur les massacres en Algérie. Sur la 
douleur. Sur notre nouvelle vie. Un silence qui court. Qui se transmet par contagion. Une vraie maladie. Une peste. Une épidémie. Silence sur toutes les lèvres" (p. 115). By likening her own silencing to the taboo surrounding the political situation in Algeria, Bouraoui reinforces Fallaize's and Kelly's insistence on the personal as political. Moreover, Nina's description of the silence as contagious, and as "une vraie maladie", underlines the important correlation between social malaise and physical disease, and thus between Bouraoui's autobiographical project and the illness narrative. The real dis(-)ease exposed by Bouraoui is a social and gendered one: Nina is dismissed as being "sick", when in reality this is simply a pretext to exert control over her body. Nina is sent for medical tests for an illness which she herself does not acknowledge: "demain, on m'examine. Mais moi je vais très bien" (p. 11). Nina is resistant to her family's attempts to label her as "unwell", and to convince her that she can be "well" if only she would desire it. This exemplifies Sontag's hypothesis that "people are encouraged to believe that they get sick because they (unconsciously) want to, and that they can cure themselves by the mobilisation of will" (IM, p. 58). Furthermore, the guilt that Nina is made to feel for her "difference" further embodies Sontag's assertion that "psychological theories of illness are a powerful means of placing the 
blame on the ill. Patients who are instructed that they have, unwittingly, caused their disease are also being made to feel that they have deserved it" (ibid). For example, Nina is made to feel that she is not "normal", and that this makes her in some way deficient: "Et moi? Quelle est ma maladie? Que cherche le docteur de la rue d'Antrain?" (p. 151). The attempt to define Nina's difference through medical diagnosis, thereby rendering it a problem that can be "solved", echoes Frank's claim that "society prefers medical diagnoses that admit treatment, not social diagnoses that require massive change in the premises of what that social body includes as part of itself' (WS, p. 113). However, Nina reveals the true sickness to be an inability to accept her difference, and an insistence that such alterity can be controlled and restricted through "treatment". This exposes the desire for medical diagnosis of social and sexual difference to be itself a social disease that is contained in and perpetuated through silence and silencing: the naming of illness imprisons the "othered" subject within categorising terminology, a sentence against which the silenced voice cannot appeal. In Nina's case, the "silencing" is of her natural impulses, as her elders attempt to appropriate the agency of her body and her habits: “Quelque chose ne va pas chez Nina. Elle n'est pas normale. Il faut la montrer. La soigner. Elle aura des problèmes, plus tard. Mais non, elle est 
féminine. Elle se met de la crème tous les soirs" (p. 52). Nina's behaviour is judged to be in need of correction, and a remedy is sought, even though Nina herself asserts that she is not sick. Thus, we see how her gendered "illness" is a socially engendered one. Indeed, this "illness" is all the more sinister for the insistence on labeling as an "abnormality" Nina's lack of conformity to restrictive stereotypes which ignore "the multiple contexts of gender and sexuality, nationalism and hybridity". ${ }^{10}$

The "illness" from which Nina is deemed to suffer remains unnamed, referred to vaguely as "des problèmes": throughout the narrative she is never referred to as lesbian, only as "pas normale". The lack of words to articulate her experience means that Nina has to find from her enforced silence the vocabulary which will eventually "heal" her. Therefore, although Nina is condemned to silence, she also draws from this silence the means by which to negotiate her survival: 'Qui m'a forcée à ça, d'ailleurs? Depuis toujours. Se taire. Garder pour soi. Intérioriser. Mon silence est un corps. Mon silence est une maison. Mon silence est une habitude. Mon silence est une forteresse" (p. 172). Nina's "interiorising" or internalising of social pressure thus results in physical "illness", or what Smith and Watson term an "ab-normative" body $(R A, \mathrm{p} .42)$. The social restrictions are implicit here, but so is the way in which Nina uses the 
instruments of her oppression to make an armour for herself. Writing thus becomes a means of overcoming, as it overturns the socio-political oppression and sexual repression forced on Nina. Nina also discovers in her voicelessness and oppression that writing is the most significant weapon she can develop against the restrictions imposed on her, and it is from the silence that she learns to find her voice: "Mon silence est un combat. J'écrirai aussi pour ça" (p. 33); "mon silence construit mon avenir" (p. 63). Therefore we see how, from the interior of the objectivised and linguistically repressed female subject, and from the socially silenced lesbian body, develops the accumulation of words as tools that Nina will use to negotiate her social identity and re-claim her gendered subjectivity. It is thus through the interiorising of silence and silencing that Nina takes on her "othered", "ill" voice, and therefore from the body that the healing voice must develop.

Social dis-ease: transmission and embodiment According to Smith and Watson, life narrators do several things in their exploration of the body and embodiment: "They negotiate cultural norms determining the proper uses of bodies. They engage, contest, and revise cultural norms determining the relationships of bodies to specific sites, behaviors, and destinies. And they reproduce, mix, or interrogate cultural 
discourses defining and distinguishing the normative and ab-normative body" (RA, pp. 41-42). In addition to these concerns of the life narrative, Frank describes embodiment as having four general problems: control, body-relatedness, other-relatedness, and desire. In this section I will highlight the ways in which Bouraoui engages with the three aspects of embodiment outlined by Smith and Watson and the four problems of embodiment cited by Frank, through her negotiations of the social repression of her "othered" lesbian body.

Throughout $G M$, there are two significant ways in which Bouraoui "negotiates cultural norms" regarding perceptions of the body and "engage[s], contest[s], and revise[s] cultural norms" vis-à-vis the relationships between the body and social expectation. On the one hand, there is the personal battle played out in Nina's body, of her natural lesbian impulses (or, to use Frank's term, “desires"), which are repressed by the silence into which she is forced (corresponding to Frank's notion of "control"). On the other hand, there is the wider social debate, as Nina's "othered" body symbolises the way in which an empirical attitude towards nationality and sexuality renders her "sick". Firstly, this exemplifies the truism highlighted by Ania Loomba, that "from the beginning of the colonial period till its end (and beyond), female bodies symbolise the 
conquered land". ${ }^{11}$ Secondly, the embodiment of social and psychological dis-ease not only corroborates my generic debate regarding the illness narrative, particularly with reference to the personal and political aspect of post-colonial and/or women's writing, but it also highlights Frank's claim that "these embodied stories have two sides, one personal and the other social" (WS, p. 2). Therefore, Nina's story can be seen as not simply a personal life narrative and quest to find her place in society, but also a social commentary, intended to function as a vessel through which to make other voices heard, voices of other repressed people who may identify with her struggle. Bouraoui challenges the cultural discourses which deem a body "normative" or "ab-normative". Indeed, her statement that "j'écris. Et quelqu'un se reconnaîtra" (p. 132) itself embodies Frank's notion that "published self-stories are another ideology, [...] [one] that calls people to the identities it formulates" (WS, p. 69). As such, Bouraoui's desire to reach out to others through her writing not only locates $G M$ firmly within the generic considerations of the illness narrative as outlined by Frank, but also opens up Frank's hypotheses in a Francophone literary context.

The body-relatedness and other-relatedness referenced by Frank are evident in the transmission that is a significant feature of Nina's dis-ease. Nina's family's troubled past weighs down on her, and is intertwined with 
wider social and historical issues: "Longtemps je crois porter une faute. Je viens de la guerre. [...] Je porte la souffrance de ma famille algérienne. Je porte le refus de ma famille française" (p. 32). Nina is tortured by her polarised identity, as it leaves her feeling that she belongs nowhere: "Ici nous ne sommes rien. De mère française. De père algérien. Seuls nos corps rassemblent les terres opposées" (p. 8). The body-related and other-related embodiment here, of the "terres opposées" and the two family lines uniting in the body, exemplify how Nina's identity crisis is primarily a social one, which becomes an "illness" through the physical incarnation of "othering". Bouraoui's claim regarding her native Algiers that "cette ville est dans le corps" (p. 91) thus not only embodies the parallel, referenced earlier, between the female body and the (formerly) colonised land, but also illustrates the intertwining of the personal and the political detailed by Smith and Watson regarding the relationship of bodies to cultural discourse.

Silence and embodiment go hand in hand in Bouraoui's life narrative, and nowhere more explicitly so that in the politicising of Nina's personal situation. Nina links her silence to that of the earth, and specifically to that of the Algerian territories: "Le silence de la terre me captive. Par là, je fonde le secret. Il me suivra longtemps. Avec le 
mensonge. Mon silence est une omission. Qui saura de quoi je suis faite? La terre algérienne" (pp. 34-35). In addition to primordial issues of embodiment (“Qui saura de quoi je suis faite?"), here Bouraoui affirms herself as Algerian, allying herself to the repressed, silenced half of her racial heritage rather than that of the dominant power. ${ }^{12}$ This creates a social and geographical dichotomy, which can be seen as metaphorically linked to illness when considered in the light of Sontag's claim that "illness is the night-side of life, a more onerous citizenship. Everyone who is born holds dual citizenship, in the kingdom of the well and in the kingdom of the sick. Although we prefer to use only the good passport, sooner or later each of us is obliged, at least for a spell, to identify ourselves as citizens of that other place" (IM, p. 3). For Bouraoui, her "good" passport, the socially acceptable or socially superior one, is linked to her French identity, but she finds it impossible to exist solely within this white, Metropolitan, patriarchal and colonial mould. The polarisation of identity is evident, as the "good", "light" aspect is affiliated to France, and the "bad", "dark" side has connotations with Africa. ${ }^{13}$ Bouraoui exemplifies Sontag's claim regarding the universal experience of dual citizenship both metaphorically through her "illness", and literally, with her "identité de fracture". However, it is not only the France/Algeria 
dichotomy which defines the difference between the "kingdom of the well" and the "kingdom of the sick", but also the models of heterosexuality and homosexuality. Bouraoui's "onerous citizenship" is, therefore, not simply a question of nationality, but also of sexuality. It is social pressure that would have Nina use the "good" passport, and it is her natural instincts and desires which oblige her to identify herself as a citizen of "that other place" (my italics). This is further linked to illness as metaphor when we consider Sontag's later claim regarding myths of illness (specifically tuberculosis and cancer), that "both are, or were, understood as diseases of passion" (p. 21). Thus, Bouraoui needs to explore and embrace her "disease of passion" before overcoming her social illness through her survival writing, and through the expression of her truth.

Conclusion: Truth, testimony, survival

Bouraoui's description of her "truth" is that of a visceral anger which stems from her repression and silencing, and which becomes as powerful as any weapon her oppressors can wield against her: "Ce sera une force vive mais rentrée. Un démon. Qui sortira avec l'écriture" (p. 129). Finding this strength and force inside herself, and channeling it through writing so that it becomes not only a testimony, but also a survival technique, Bouraoui's writing of anger situates her within a strong feminist and post- 
colonial framework, as many works of emancipation have sprung from a violent reaction to the oppression of the female and/or colonised subject. ${ }^{14}$

Nina's efforts to transcend her struggle with gendered identity culminate in her rejection not only of her feminine role, but also of the ambiguous label of "garçon manqué”: "Tu es un garçon manqué. Non. [...] Je suis" (p. 64). Bouraoui rejects the "tomboy" implications of "garçon manqué", which mask the truth of her gendered subjectivity. ${ }^{15}$ She affirms herself as subject, claiming simply that "je suis", and refusing to be trapped within categorising notions of gender and sexuality. Consistent with the reversal of oppression into defense, Bouraoui also negotiates her survival through language, via the conversion of silence into writing: "Mon silence est un combat. J'écrirai aussi pour ça" (p. 33). Crucial to this insurrection is a re-appropriation of the self through language. Bouraoui ends $G M$ with a reflection on the chatter of Italian children during a visit to Rome: "Ils me parlaient. Et, sans connaître la langue, je savais que toute ma force était là, dans leurs mots, dans leurs chansons, dans la nouveauté qui hantait mon corps: le désir" (p. 186). The fact that these are voices of children, as yet indiscriminate regarding their acceptance of the sexual "other" - and Italian, unaware of the national and racial tensions in post-colonial Algeria - suggests an innocent anonymity in the relationship between the self and 
the other, which is crucial to Nina's well-being. The battle between desire and control, between body-relatedness and other-relatedness (these being the four problems of embodiment outlined by Frank), is thus won by desire and by Nina's own body (or body-relatedness), power eventually emanating from "la nouveauté qui hantait mon corps: le désir" (my italics). In hearing a language she does not understand, Nina finds in it her own identity, free from the linguistic constraints exerted over her by her social position in Algeria and by her sexual status as "pas normale". The conclusion of $G M$ is thus consistent with Julia Kristeva's metaphor of "le cordon ombilical qu'est la langue nationale et ses codes traditionnels": ${ }^{16}$ for Nina, salvation is dependent not only on breaking the silence imposed on her, but also on gaining linguistic autonomy through a positive separation from the land and, by extension, from the constraining social situation in which she is bound. While Bouraoui does not wish to break with her cultural heritage, nonetheless she must effect a positive rupture with her metaphysical "umbilical cord" by finding her own language, one which neither categorises (as with the term "garcon manqué), nor refuses to name reality (as with the label "pas normale").

It is in finding linguistic "truth" that Bouraoui not only effects her own "healing", but also creates a testimony to be taken forward, thus 
epitomising Frank's assertion that "as a post-colonial voice, the storyteller seeks to reclaim her own experience of suffering. As she seeks to turn that suffering into testimony, the storyteller engages in moral action" (p. 18). Hence, we see that through the personal crusade of the autobiographical project, Bouraoui renders her quest a collective one: Overcoming the silence, she embodies the dis(-)ease and instead of transmitting it, as it has been transmitted to her, she transforms it into an articulated truth in this life narrative. Her rejection of "normality", or the "kingdom of the well", and her consequent decision to explore the "night side of life", or the "kingdom of the sick", reinforces Frank's assertion that "society is suppressing a truth about suffering, and that truth must be told. These writers do not want to go back to a former state of health, which is often viewed as a naïve illusion. They want to use suffering to move others forward with them" (WS, p. 121). The "naïve illusion" of a racially "pure", heterosexual, patriarchal community is shattered in Bouraoui's narrative, exposed as being not a "state of health", but a restraining and damaging condition, the reality of which is the true "sick" mentality. However, the truth about Nina's "illness" is dangerous: as Sontag elucidates, "any disease that is treated as a mystery and acutely enough feared will be felt to be morally, if not literally, contagious" (IM, p. 6). Bouraoui's subversion 
of "normality" in $G M$ thus becomes a positive "contagious" rally to "nonstandard", "othered", or "ab-normative" social groups, her life narrative exemplifying Frank's claim that "as wounded, people may be cared for, but as storytellers, they care for others" (WS, p. xii). The caring demonstrated by Bouraoui is in the telling of her truth, which Frank describes as the offering of the "illl" (WS, p. 145). Claiming that "c'est dangereux, un écrivain. C'est obsédé par la vérité. Par sa vérité” (p. 136), Bouraoui inscribes her truth onto the narrative, challenging cultural perceptions of the "normative" and "ab-normative" body through her embodiment of dis-ease, and its transformation into overcoming by finding her silenced, "othered" voice.

Helen Vassallo

Department of French

University of Exeter

Exeter EX4 4QH

United Kingdom

NOTES

${ }^{1}$ N. Bouraoui, Mes Mauvaises Pensées (Paris, 2005); Garçon manqué (Paris, 2000). Further page references to Garçon manqué (GM) are given in the text. While some articles have been written on Bouraoui's first prize- 
winning novel La Voyeuse interdite (Prix du Livre Inter, 1991), GM, along with the majority of Bouraoui's œuvre to date, remains unexplored in published academic criticism, except for three articles. Firstly, Martine Fernandes discusses sexuality and selfhood in "Confessions d'une enfant du siècle: Nina Bouraoui ou la 'batarde' dans Garçon manqué et La Vie heureuse", L'Esprit Créateur 45.1 (2005), pp. 67-78. While Fernandes gives an interesting overview of the narrative, she does not consider it outside Lejeune's definition of "traditional" autobiography, although her focus on the importance of the Algerian war in the narrative is picked up in Ching Selao's discussion of post-colonial tensions and oppressions in “Porter l'Algérie: ‘Garçon manqué' de Nina Bouraoui”, L'Esprit Créateur 45.4 (2005), 74-84. Finally, in the recent online article "“Garçon manqué' de Nina Bouraoui: Regards linguistiques et thématiques sur une ambiguïté identitaire", Lianes 1, Nelly Foucher Stenkløv and Priscilla Ringrose discuss theories of globalisation with regard to the narrative but, again, do not question their categorisation of $G M$ as "autobiography".

${ }^{2}$ Sidonie Smith and Julia Watson define "life narrative" as a genre which "calls into question a narrowed definition associated with [...] canonical or traditional autobiography", in which "narrators selectively engage their lived experience through personal storytelling”. S. Smith and J. Watson, 
Reading Autobiography: A Guide for Interpreting Life Narratives (Minneapolis, 2001), pp. 197, 14. Further page references to Reading Autobiography $(R A)$ are given in the text. Bouraoui's insistence on social and sexual repression represents the "selective" engagement outlined by Smith and Watson, while separating from the typically colonial and maledominated tradition of "canonical" autobiography.

${ }^{3}$ A. Frank, The Wounded Storyteller: Body, Illness, and Ethics (Chicago, 1997); Susan Sontag, Illness as Metaphor and AIDS and its Metaphors (New York, 1990). Further page references to The Wounded Storyteller (WS) and Illness as Metaphor (IM) are given in the text.

${ }^{4}$ E. Fallaize, French Women's Writing (London, 1993), p. 23, D. Kelly, Autobiography and Independence (Liverpool, 2005), p. 7.

${ }^{5}$ P. Lejeune, Le Pacte autobiographique (Paris, 1975), p. 14.

${ }^{6}$ D. Stanton, “Autogynography: Is the Subject Different?”, The Female Autograph: Theory and Practice of Autobiography from the Tenth to the Twentieth Century, ed. by Domna C. Stanton (Chicago, 1987), 3-20 (p. 14).

${ }^{7}$ Elizabeth Spelman has criticised such a tendency to homogenise female experience into a Western, colonial mould, in her claim that "the focus on women 'as women' has addressed only one group of women - namely, 
middle-class women of Western industrialised countries." E. Spelman, Inessential Woman: Problems of Exclusion in Feminist Thought (Boston, 1988), p. 3.

${ }^{8}$ M. Sheringham, French Autobiography: Devices and Desires (Oxford, 1993), p. viii; L. Hewitt, Autobiographical Tightropes: Simone de Beauvoir, Nathalie Sarraute, Marguerite Duras, Monique Wittig and Maryse Condé (Nebraska, 1990), p. 6.

${ }^{9}$ While "memory" and "experience" can also be identified as essential components of autobiography, "identity" and "agency" are particularly important to the female and post-colonial narrative, and the notion of "embodiment" is similarly crucial to the illness narrative. Therefore, it is by applying the particularities of Smith and Watson's understanding of the life narrative that I posit $G M$ outside the generalities of the more catch-all notion of autobiography.

${ }^{10}$ A. Loomba, Colonialism/Postcolonialism, p. xvi.

${ }^{11}$ Colonialism/Postcolonialism, p. 152. This generates a further link with the metaphor of illness, as Sontag outlines how the vocabulary of cancer treatment has "a military flavour", colonising the ill body (IM, pp. 66-69). 
${ }^{12}$ This is a common trend in contemporary Francophone women's writing. For example, Jeanne Hyvrard believes that through her status as a woman - and thus a social subordinate - she is affiliated with all marginalised and/or oppressed groups ("I would say that as a woman I am a native of the Caribbean [...] I saw in the loss of identity that the natives of the Caribbean experience what had happened to me as a woman.” E. Fallaize, French Women Writers, pp. 110-111).

${ }^{13}$ The importance of this polarised view is particularly relevant to issues of gender, recalling as it does Hélène Cixous' denunciation of binary thinking in La Jeune Née (Paris, 1975), and her criticism of perpetuations of this separatist stereotype, such as in Freud's depiction of Africa and the female body as the "dark continent".

${ }^{14}$ For example, Monique Wittig's depiction of female utopia in Les Guérillères (Paris, 1969), Hélène Cixous's assertion of female love in Le Livre de Promethea (Paris, 1983) and Audre Lorde's essays and speeches on the position of black (lesbian) women in twentieth-century American society in Sister Outsider: Essays and Speeches (New York, 1984). ${ }^{15}$ The French term "garçon manqué" makes this an interesting subject for debate. The English equivalent "tomboy" simply implies a girl whose recreational behavior is not traditionally "feminine", but something she 
may grow out of, as the term is usually applied only to children. However, the French term not only applies a masculine noun and adjective to a feminine subject, but also connotes the idea that the female subject should have been born a boy, which raises problematic issues of gendered identity. For Nina, this evokes the question of her sexuality, and the taboo of being a woman who loves women in a masculinist society.

${ }^{16}$ J. Kristeva, "L'autre langue ou traduire le sensible", French Studies 52.4 (October 1998), 385-396 (p. 396).

\section{WORKS CITED}

Bouraoui, N., Garçon manqué, (Paris, 2000).

Fallaize, E., French Women's Writing (London, 1993).

Frank, A., The Wounded Storyteller: Body, Illness, and Ethics (Chicago, 1997).

Hewitt, L. D., Autobiographical Tightropes: Simone de Beauvoir, Nathalie Sarraute, Marguerite Duras, Monique Wittig and Maryse Condé (Nebraska, 1990).

Kelly, D., Autobiography and Independence (Liverpool, 2005).

Kristeva, J., "L'autre langue ou traduire le sensible", French Studies 52.4 (October 1998), pp. 385-396.

Lejeune, P., Le Pacte autobiographique (Paris, 1975). 
Loomba, A., Colonialism/Postcolonialism (London, 1998).

Sheringham, M., French Autobiography: Devices and Desires (Oxford, 1993).

Smith, S., and J. Watson, Reading Autobiography: A Guide for

Interpreting Life Narratives (Minneapolis, 2001).

Sontag, S., Illness as Metaphor and AIDS and its Metaphors (New York, 1990).

Spelman, E., Inessential Woman: Problems of Exclusion in Feminist Thought (Boston, 1988).

Stanton, D. C., “Autogynography: Is the Subject Different?”, in: The Female Autograph: Theory and Practice of Autobiography from the Tenth to the Twentieth Century, ed. D. C. Stanton (Chicago, 1987), pp. 3-20. 